\title{
THE NEW CAPITAL ADEQUACY FRAMEWORK: \\ Institutional Constraints and Incentive Structures
}

\author{
Prepared by Cem Karacadag and Michael W. Taylor*)
}

*) This paper first appeared in the IMF Working Paper Series No. 00/93, June 2000. A different version of the paper was given at the SUERF Colloquium in Vienna in April 2000.

Société Universitaire Européenne de Recherches Financières

Vienna 2000 
CIP

Cem Karacadag and Michael W. Taylor

The New Capital Adequacy Framework: Institutional Constraints and Incentive Structures Vienna: SUERF (SUERF Studies: 8)

ISBN 3-902109-00-9

JEL Classification Numbers: G21

Keywords: Capital regulation, bank capital, rating agencies, prudential supervision

\section{(C) 2000 SUERF, Vienna}

Copyright reserved. Subject to the exception provided for by law, no part of this publication may be reproduced and/or published in print, by photocopying, on microfilm or in any other way without the written consent of the copyrightholder(s); the same applies to whole or partial adaptions. The publisher retains the sole right to collect from third parties fees payable in respect of copying and/or take legal or other actions for this purpose. 


\begin{abstract}
This paper considers the implementation challenges facing the Basel Committee's new proposals on bank capital standards. When compared with the existing Capital Accord, the proposals represent a shift across two intersecting dimensions-regulatory versus economic capital, and rules-based versus process-oriented regulation. On minimum capital standards, the case for using external ratings may be stronger than has been recognized, given the divergences in the purpose and design of internal ratings. On supervisory review, ensuring comparability among supervisors and building supervisory capacity will present serious challenges. On enhancing market discipline, incentives for markets to exercise discipline will be required.
\end{abstract}

The authors wish to thank Charles Enoch, Huw Evans, Carl Lindgren, and Jan Willem van der Vossen for their valuable insights and comments. We also thank Anthony Saunders and Berry Wilson who provided data on capital ratios in Canada, the United Kingdom, and the United States. The views expressed in this paper are those of the authors and do not necessarily express those of the IMF or IMF policy. 



\section{Contents}

$\begin{array}{lll}\text { I. Introduction } & 7\end{array}$

II. The Problem Stated 11

III. A Conceptual Map for Analyzing Capital Requirements 17

$\begin{array}{ll}\text { A. Regulatory versus Economic Capital } & 17\end{array}$

B. Rules versus Process-Oriented Regulation 18

C. Locating the 1988 Accord on the Conceptual Map 20

D. Locating the NCF on the Conceptual Map 22

IV. The First Pillar: Minimum Capital Requirements 27

$\begin{array}{ll}\text { A. Credit Ratings } & 27\end{array}$

$\begin{array}{ll}\text { The accuracy of ratings } & 27\end{array}$

Risk analysis and ratings as public goods 28

Criteria for the regulatory recognition of rating agencies 29

The U.S. Securities and Exchange Commission's NRSRO designation 32

B. Internal Rating Systems 34

$\begin{array}{ll}\text { Credit risk models } & 37\end{array}$

C. Preliminary Conclusions on the First Pillar 38

V. The Second Pillar: Supervisory Review 41

VI. The Third Pillar: Market Discipline 47

A. Conditions for Market Discipline: Are They Satisfied? 47

VII. Conclusion $\quad 53$

Charts

1. Capital Ratios for Canada, U.K., and U.S. (1893-1993) 12

2. Capital Regulation Through Time 24

Tables

1. Top 20 World Banks’ Assets 45

$\begin{array}{ll}\text { References } & 55\end{array}$ 



\section{Introduction}

This paper develops a conceptual framework for assessing the major reorientation in bank capital adequacy regulation proposed in the Basel Committee's New Capital Framework (NCF) consultative document. ${ }^{1}$ The NCF document outlines a series of measures which, taken collectively, amount to a fundamental revision to the Committee's 1988 Capital Accord ("Accord"). Intended only to apply to internationally active banks, and representing an informal agreement between the central banks and bank supervisory agencies of the G-10 countries, the Accord has since become accepted as the de facto universal international standard for assessing banks' capital adequacy. Thus, a proposal to revise the Accord is a matter of immense significance for the international financial system.

The primary aim of this paper is to develop a conceptual framework in which both the Accord and the NCF can be grounded. This conceptual framework or map as we call it - rests on two intersecting dimensions (1) regulatory capital versus economic capital, and (2) rules-based capital regulation versus process-oriented capital regulation. The NCF represents a shift across both dimensions of our conceptual map: from a rules-based to a process-oriented approach to supervision of capital adequacy; and from a regulatory approach to setting capital toward one based on economic capital allocation mechanisms. While the NCF offers important theoretical advantages over the Accord, these advantages can only be realized if a number of implementation challenges are overcome in both developed and developing financial markets.

The paper then turns to a critical analysis of the three "pillars" upon which the $\mathrm{NCF}$ is built - minimum capital requirements, supervisory review of capital adequacy, and market discipline. These three pillars are critically interdependent and the NCF's success hinges on ensuring the proper functioning of all three of them. Supervisory review is vital to ensure that capital allocation processes are sound and utilized effectively. Market discipline, in turn, is necessary to provide incentives for banks to manage their risks prudently and for supervisors to perform their tasks in a manner

\footnotetext{
${ }^{1}$ The IMF Staff have submitted comments to the Committee on the proposed revisions to the capital adequacy framework. This paper, although not formally linked to the comments, aims to provide background to the comments and to discuss some of the key issues in greater depth.
} 
that instills market confidence. This paper identifies challenges associated with each of the three pillars and generates recommendations on how they might be overcome.

On the first pillar, the NCF's hallmark proposal to place greater reliance on internal processes to set capital is well-reasoned, but underestimates the difficulty of ensuring their accurate and consistent application within and across national borders. Even among large internationally active banks, internal rating systems differ widely in terms of purpose, design, and degree of sophistication, while their accuracy is rarely back-tested or validated. Without establishing the ultimate benefits and limits of internal systems, it may be premature to endorse their wholesale adoption for regulatory purposes until a clear consensus on best practices emerges.

As an alternative to the internal processes approach, the NCF proposes a refinement to the existing capital framework based on ratings assigned by external credit rating agencies. Our analysis of the pros and cons of external ratings and internal rating systems suggest that the use of external credit ratings, on balance, may involve relatively fewer disadvantages. External ratings are more stable than market prices and less procyclical than internal ratings. Moreover, achieving accuracy and consistency in the methodologies and quality of ratings among a dozen or more recognized rating agencies will prove easier than doing the same for the internal rating systems of a much larger number of banks with a wider range of practices.

To the extent that external ratings are adopted, we stress the importance of having rigorous approval criteria, and draw lessons from the Securities and Exchange Commission (SEC)'s experience on designating "Nationally Recognized Statistical Rating Organizations" (NRSROs) in the United States. In particular, the approval criteria should rely heavily on market feedback and the track record criterion should be tightened considerably. Given the "public good" attributes of ratings, and the need to ensure the consistent application of approval criteria, there is a strong case for centralizing the recognition of rating agencies, perhaps in the Bank for International Settlements (BIS).

If supervisors rely on banks' own internal capital allocation processes to set capital, the second pillar - supervisory review of capital adequacy and supervisory judgment - will move to the center stage of capital regulation. In this context, another pair of fundamental concepts - supervision versus regulation - is introduced in order to identify why supervision lost out to regulation in the past, but why conditions might now be ripe for supervision 
to reassert itself. In the past, regulation became the preferred approach to overseeing banks because of the human capital intensity of a judgment-based, case-by-case approach to supervision, which became difficult to exercise in large and diversified banking sectors. Supervision, as opposed to regulation, traditionally has been associated with banking systems in which a few, relatively large institutions form a "club" type arrangement. The consolidation of the banking industry in the leading G-10 countries may be creating the conditions under which this type of supervision may be a realistic option for a set of large, internationally active banks. Nonetheless, ensuring international comparability and consistency of treatment among supervisors when judgment supersedes rules will require the development and use of peer-group review mechanisms. Furthermore, it will require years of technical assistance to bring the supervisory capacity of many emerging economies up to the standard necessary to make supervisory review an effective part of bank capital regulation.

With regard to the third, market discipline pillar, we examine the preconditions for effective market discipline and whether they are satisfied in developed and developing countries alike. While disclosure is a necessary condition for market discipline, it is not sufficient. Incentives must exist for market agents to exercise discipline and governance structures must be conditioned to generate the desired response. Specific measures that could enhance the effectiveness of market discipline include disincentives against the provision of inaccurate information, designing incentive-compatible safety nets, and opening the financial sector to foreign competition.

A subsidiary concern of this paper is the applicability of the NCF to emerging markets. It is evident that the preconditions for implementing important components of the NCF are absent in most emerging market economies. Weak legal and regulatory institutions, and the limited human resource capacities of supervisory agencies, will impair the effectiveness of supervisory review in evaluating capital adequacy. Similarly, without efficient markets that send appropriate signals, and corporate governance structures that respond to them, market discipline cannot play a meaningful role in promoting financial system soundness. With the preconditions for the second and third pillars not satisfied, the first pillar will be the only operative pillar in emerging markets, at least during a transitional period. While the three-pillar approach to capital adequacy will provide strong incentives for developing countries to strengthen supervisory capacities and governance structures, transitional arrangements may be required to ensure that the first pillar delivers higher levels of capital in emerging market banking systems. 



\section{The Problem Stated}

This section reviews the key features of the Accord and the reasons motivating the Committee's proposal to revise it. While both the Accord and the NCF share the same objectives of promoting safety and soundness in financial systems and enhancing competitive equality among them, the NCF represents a significant departure from the Accord in terms of the principles it embraces and the methods it employs. This section highlights key tradeoffs among elements of the new framework - for example, between the accuracy of capital charges and comparability of capital ratios. What becomes clear is that the NCF's objectives are not all achievable at once: trade-offs exist and choices have to be made, but the NCF's sacrifice of the verifiability and comparability of capital ratios in return for greater accuracy is well-founded.

The Accord has three main features. In the first place, it is concerned only with large, internationally active banks. Secondly, it is concerned primarily with credit risks, although the need for other risks to be incorporated was recognized at its inception and the Accord has since been amended to reflect this (most notably in the form of the 1996 Market Risk Amendment). Thirdly, it provides an avowedly crude and simple methodology for assessing capital adequacy. Nonetheless, the Accord's simplicity helps secure the goals of comparability and verifiability; by subjecting all banks to a common risk measurement framework, the Accord produces a single metric, in the form of the 8 percent capital ratio, against which they can be compared and judged.

Despite these advantages, almost from the outset the Accord was criticized for its failure to incorporate key insights of the theory of finance. Most notably, its risk measurement framework does not generate a capital advantage for banks that have well-diversified portfolios, even though finance theory indicates that they should be treated as less risky than banks with concentrated portfolios. Moreover, its system of four risk "buckets" (of $0,20,50$, and 100 percent respectively) has been criticized as being too crude, and the 8 percent minimum capital ratio has been rejected as arbitrary. Finally, the different risk weightings the Accord assigned to OECD and nonOECD members were criticized first on the grounds that they were arbitrary and politically motivated; and subsequently because, with the expansion of the OECD's membership, they appeared to favor some countries that were 
less creditworthy than other non-OECD members. ${ }^{2}$ These and other features of the Accord, it has been argued, have resulted in distortionary effects in international banking markets.

The Accord's distortionary effects may have become more pronounced in recent years. During the period when many developed and developing country banking systems had not yet met minimum capital requirements, comparability across banks and countries provided strong incentives to achieve the minimum standard. To its credit, the Accord has successfully met its primary objective, which was to stop, and then reverse, the secular decline in banks' capital experienced throughout much of the twentieth century (see Chart 1). But once achieved, the transparency and verifiability of capital ratios may have had the opposite effect; engendering a degree of complacency among regulators, market participants, and banks. The achievement of the minimum requirement may have been overweighted in the evaluation of bank and systemic soundness, without due regard to asset quality, loan valuation, and loss recognition, which are essential complements of capital adequacy.

Chart 1. Capital Ratios for Canada, U.K., and U.S. (1893-1993)

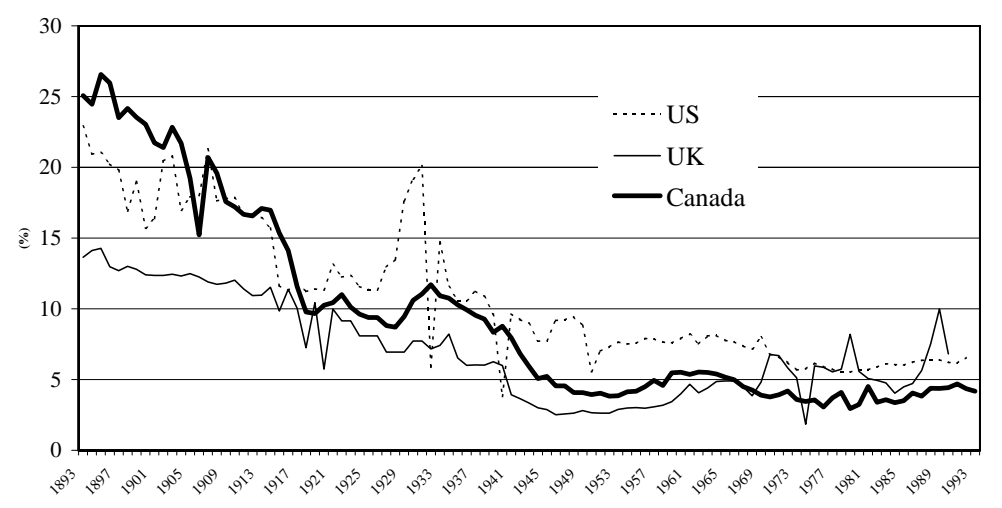

Source: Saunders and Wilson, 1999

The simplicity, comparability, and verifiability of capital ratios, in fact, may have given markets a false sense of certainty and security, especially as the capitalization of most banking systems worldwide surpassed the 8 percent

\footnotetext{
${ }^{2}$ The Mexican peso crisis in 1995 occurred shortly after Mexico had been admitted to OECD membership. The Republic of Korea is another example of a country suffering a severe financial crisis subsequent to being admitted to the OECD.
} 
minimum. For example, a bank with a nominally high capital ratio of 12 percent normally would be characterized as "well-capitalized," given the Basel minimum CAR of 8 percent. Yet, a 12 percent ratio may be inadequate for the bank's operating environment and risk profile, which may warrant a capital ratio of 15 or 20 percent in the economic sense ${ }^{3}$ (Greenspan, 1998). Indeed, prior to the 1997-98 Asian financial crisis, many of the region's banking systems were considered adequately or well-capitalized on the basis of Basel capital adequacy ratios, which clearly misrepresented the solvency of banks and their ability to cope with economic stress. The existence of an officially sanctioned quantitative benchmark lends itself to misuse as quantitative indicators are perceived as more tangible, sometimes without due regard to their analytical value. This risk is compounded by the difficulty of analyzing and pricing uncertainty, which predisposes market participants to seek certainty, however misleading it may be.

The Accord has also come under pressure as a result of several other important developments. First of all, a decade of innovation by financial markets, in some cases with the intention of circumventing the Accord, has eroded its effectiveness. For example, neither securitization nor credit derivatives are adequately captured within the existing framework of the Accord, which is cast largely in terms of banks' conventional on-balance sheet risks. Moreover, in parallel to this development, risk management systems employed by the most sophisticated, internationally active banks have undergone what can only be described as a "step change" during the 1990s. As a result of rapid innovation in risk measurement technologies employed by banks, the Accord has come to appear increasingly dated.

At the same time, the Accord has been presented with the challenge of becoming accepted as the de facto standard that is applied by most supervisors around the world. Its status as the international standard for bank capital adequacy has been cemented by reference to it in the Basel Core Principles for Effective Banking Supervision. This development has placed a burden on the Accord that it was never intended to bear. In particular, it has led to its application in the emerging market and developing economies, where many of its necessary preconditions are absent. Without proper rules on asset valuation, loan loss recognition and provisioning, and an effective legal infrastructure that permit banks to enforce the terms of debt contracts,

\footnotetext{
${ }^{3}$ In fact, supervisory authorities in many countries, including Argentina, Bahrain, Brazil, Estonia, India, Hong Kong SAR, Kuwait, Latvia, Singapore, Thailand, and Uganda have implemented higher CARs ranging from 8.5 percent to 12 percent.
} 
any capital adequacy assessment based on the Accord's methodology is bound to be misleading. Yet this is precisely the context in which the Accord is being used by many supervisory authorities today. This has also been at the root of the problems in transposing the Accord into non-G-10 countries and will remain a challenge in implementing the NCF in parts of the world.

The main innovations of the NCF compared with the Accord are, first, that it aims to bring the methodology of calculating capital requirements more closely into line with the advances in risk management technology that have occurred since 1988 and, second, that it aims to move capital regulation in a more process-oriented direction. Hence, the NCF aims to go further than simply bringing a number of innovative financial instruments within the scope of the Accord. It does not merely aim at an ex post adjustment of the Accord to accommodate market developments. It also aims to be forwardlooking by making capital standards less distortionary ex ante. The overall objective is to limit the incentives that capital standards create for banks to arbitrage its requirements by more closely aligning capital charges with loss risks. Ultimately, the NCF's emphasis is on the need to deal with market innovations rather than the problems of the standard's application to emerging markets, and a major objective of the consultation document is to accommodate the market developments that have transformed the nature of credit risk in banking.

Whereas the original Accord laid down a series of simple rules in order to develop a common metric for setting bank capital requirements, the NCF envisages an approach in which supervisors will become less involved in determining the precise rules of calculating capital adequacy. Instead, supervisors will concentrate on ensuring that a bank's internal risk management procedures (and, hence, its internal systems for allocating capital) are adequate. In this paper we refer to this as a shift from rules-based to process-oriented regulation.

The approach outlined in the NCF is, in fact, an extension of the approach already adopted in the 1996 Market Risk Amendment. This Amendment to the Accord permitted banks to use their own internal Value at Risk (VaR) models to calculate capital needed for market risk, provided that the model and the risk management procedures in which they were embedded could meet certain conditions. While statistically based credit risk models represent a counterpart to the VaR models permitted by the Market Risk Amendment, they are too underdeveloped yet to be accepted for regulatory purposes. The conceptual and practical problems that remain with these models have been 
serious enough for the Committee to reserve its position on their use, although leaving open the option for their adoption in the future. In the interim, it has sought to move capital regulation in a process-oriented direction based on the proposal to use banks' own internal credit rating systems as the basis for capital allocation.

Like the market risk amendment, the NCF also offers a "standardized" approach as an alternative to the process-oriented one. This is a refined version of the original Accord framework, although with the variation that the risk "buckets" will become more differentiated, and ratings generated by the rating agencies will become the basis for allocating capital. However, although the emphasis given to the rating agencies is an important innovation, the fundamental reorientation in regulatory approach to setting bank capital occurs with the Committee's process-oriented approach to setting bank capital. While setting capital charges according to external credit ratings is a mere refinement of the current minimum standards, basing capital charges on internal ratings systems is an entirely different approach to bank capital, which rests on the regulatory assessment of the process by which capital is allocated.

We now turn to laying out a conceptual map on which the theoretical and practical underpinnings of the Accord and the NCF can be grounded. 



\section{A Conceptual Map for Analyzing Capital Requirements}

This section develops two contrasting pairs of concepts, which provide the essential underpinning to an evaluation of the NCF's aims and objectives. These are (1) the contrast between economic and regulatory capital; and (2) the contrast between rules-based and process-oriented capital regulation. These pairs of concepts are best thought of as "ideal types" or models to which the actual capital regulations can conform in varying degrees. They are nonetheless useful in providing a frame of reference for the analysis of the innovative features of the NCF.

\section{A. Regulatory versus Economic Capital}

The difference between regulatory and economic capital occurs across two dimensions. The first relates to the actual quantum of capital held; the second concerns the methodology that is employed to calculate this quantum.

With regard to the first of these dimensions, economic capital can be defined as the quantum of capital that a firm determines is prudent, desirable and achievable over the long term in the absence of regulatory requirements (Berger et al, 1995). The purpose of economic capital is primarily to limit the probability of bank failure, according to the owners' subjective assessment of the probability of failure, and secondarily to finance bank activities. Internal capital allocation processes, therefore, aim to ensure that sufficient capital is set aside for the risks undertaken by the bank. Shareholder value is maximized when long run risk-adjusted return on equity is maximized. One method of quantifying the risk adjusted return is to measure returns - net of expected losses - against the capital that should be allocated to a transaction to reflect that transaction's risk. On the margin, the level of capitalization equates the marginal benefit of gearing with the private costs of failure (Schaeffer, 1992). The "bank-specific" equilibrium level of capital is precisely where a bank aspires to be and which it targets as an optimum from the standpoint of its shareholders.

The difference between economic and regulatory capital is that the latter takes into account the public costs of bank failure (Schaeffer, 1992). Given the systemic costs associated with individual bank failures, regulators want to ensure that negative externalities are incorporated into banks' pricing decisions. However, the essence of economic capital is that it is only 
18 A Conceptual Map for Analyzing Capital Requirements

concerned with the private costs of bank failure, not with the costs that it might potentially impose on the rest of the financial sector or on the real economy. Since regulation exists to ensure that these costs are taken into account by participants in the financial markets, regulatory capital requirements should be set at levels that require participants to take account of these costs. In consequence, regulatory capital is likely to require banks to maintain more capital than they would hold otherwise according to their internal capital allocation systems.

Economic and regulatory capital can also differ according to the methodology that is employed to calculate the required quantum of capital. In principle, the method for calculating both types of capital can be rules-based or processbased. In practice, regulators have tended to accept industry-standard approaches to setting capital, rather than creating their own methodology of capital calculation, and thus the methods for calculating the two types of capital have not diverged significantly until recently. In periods of rapid technological development (as occurred during the 1990s) regulatory methodologies may lag behind those used by the industry, since regulatory standards evolve less rapidly than those used in the industry. ${ }^{4}$

\section{B. Rules versus Process-Oriented Regulation}

The second set of contrasting concepts on which this paper relies is the dichotomy between rules- and process-oriented regulation. Rules-based regulation sets prescriptive standards that regulated firms are required to follow. In the context of capital regulation, it relies largely on the application of simple mechanical formulas for assessing how much capital a bank should be required to hold. Rules-based regulation thus aims for consistency across institutions - indeed, it might be criticized on the grounds that it adopts a "one-size-fits-all" or "cookie cutter" approach to assessing risk. The essence of this approach is that it represents an attempt to monitor the prudential soundness of banks by using a standardized risk measurement framework, which is applied to all institutions and which employs data based on a snapshot of their balance sheets on certain specified reporting dates. The approach is standardized since regulators specify the precise form in which the calculation of the capital adequacy is to be performed - for example, the specific risk categories to which assets are assigned. It is also a calculation

\footnotetext{
${ }^{4}$ For example, the regulatory methodology is often written into formal regulations or legislation, which requires time to change.
} 
that is intended to be performed only periodically, reflecting the assumption that that credit risk (i.e., the risk of borrower default) is the main type of risk arising from banking activity, and problem loans can be detected sometime in advance of default. If a loan goes bad, provisions can be made, and possibly a workout organized. It is not necessary to monitor these risks on a real-time basis, while the skills called for in monitoring them are those of credit analysis and audit.

By contrast, a process-oriented approach rejects both the ideas of standardization and that periodic reports are a sufficient basis on which to assess a bank's financial soundness. Standardization is inappropriate, it is argued, because capital adequacy must vary according to the quality and character of a bank's assets, the competence of its management, and the stability of the environment in which it operates; no simple mechanistic formula can adequately reflect these factors (Estrella, 1998). While this has always been true, advances in technology and product innovation have made mechanistic formulas ever more inadequate as a means of assessing capital adequacy, since it is not possible to predetermine a set of rules that will capture all aspects of the risks incurred by banks given the dynamic, evolving character of the industry. This dynamism has also undermined the traditional approach based on periodic reporting to supervisors. As Greenspan has remarked:

"The use of new technology and instruments in rapidly changing financial markets means that some bank balance sheets are already obsolescent before the ink dries. They are not even necessarily indicative of risk exposures that might prevail the next day. In such a context, the supervisor must rely on his evaluation of risk management procedures as a supplement to and in extreme cases, a substitute for - balance sheet facts. As the 21st century unfolds, the supervisors' evaluation of safety and soundness, of necessity, increasingly will be focused on process, and less on historical records (Greenspan, 1996)."

Thus, an emphasis on the adequacy of processes is to take the place of standardization and periodic reporting. Instead of prescribing rules for assessing capital adequacy, the supervisors should aim to assess the adequacy of the internal processes used by firms to assess their own risks.

There are a number of important differences between process- and rulesbased regulation. First, process-oriented regulation is harder to implement 
given the diversity of internal systems in banks and the discretion involved in reviewing the adequacy of capital allocation mechanisms. Second, it incorporates measures determined by each individual bank using proprietary information, which the firm may be reluctant to make public on competitive grounds. Third, given that processes rely on institution-specific and proprietary information, they are difficult to replicate and validate, and therefore less transparent. Fourth, by design and in practice, process-oriented regulation does not aim to subject all banks to a common risk assessment framework and hence is not readily comparable across firms. In all these respects, process-oriented regulation is the exact opposite of rules-based regulation.

This pair of contrasts provides a conceptual map for navigating through the differences between the Accord and the NCF. In essence, the framework envisaged in the NCF involves a move across two dimensions (1) from regulatory to economic capital; and (2) from rules to process-oriented regulation. The change is a matter of degree, not of kind; it is not all-ornothing. Thus, the NCF retains elements of regulatory and rules-based capital regulation, just as the Accord incorporated elements of economic and processoriented approaches. Nonetheless, the change in regulatory approach represented by the NCF is substantial and important, and occurs across both of these dimensions at once.

\section{Locating the 1988 Accord on the Conceptual Map}

The 1988 Accord features both the regulatory and rules-based features discussed above. The Accord stipulated capital as a minimum, and the minimum level chosen (i.e., 8 percent of risk-adjusted assets) generally exceeded the capitalization of the banking sectors of the G-10 economies in the late 1980s. To this extent, it imposed on banks a higher level of capital adequacy than they had been prepared to hold in the absence of regulation. This is consistent with our characterization of regulatory capital as setting a higher standard than economic capital, given that it also takes into account the social costs of firm failure.

Regulatory capital in the Accord is derived on the basis of a simple, relatively crude method, albeit one that in the mid-1980s did not diverge greatly from industry practice. Although the Accord required banks to raise their capital ratios, its method of calculating capital adequacy was not that far apart from the methodology then employed by banks to assess capital for economic purposes. In other words, it was the Accord's 8 percent minimum capital ratio 
requirement that had the clearest impact on banks, rather than the specific mechanism it required them to adopt to calculate their capital adequacy. The pressures on the Accord that have developed over the last decade have arisen in part because advances in risk management technology have outstripped the simple, mechanistic model on which the Accord relies (Taylor, 1998).

The Accord also approximates to what we have termed a rules-based approach. Its aim was not to produce a precise quantification of risk, but a first-order, comprehensive approximation based on the application of a number of simple rules. This conferred it with a number of advantages. First, a rules-based approach is easy to implement. Second, it is an objective measure that is easily verifiable and reproducible. Third, as a common metric, it is comparable across institutions worldwide and promotes competitive equality among banking industries.

Nonetheless, process-oriented regulation also had its place in the Accord, albeit in a subordinate role. The authors of the Accord recognized the limitations of their methodology and intended that it be supplemented by a process of supervisory review, which would involve an assessment of the risk management capacity and processes of individual banks. For example, the Accord left out a number of risks to which banks are potentially exposed, most notably concentration risk and operational risks, especially those deriving from inadequate systems and controls. The 8 percent capital requirement was explicitly intended to be a minimum, and a process of supervisory review was meant to determine the appropriate circumstances for setting a higher capital requirement based on these additional risk factors. It was also implicit in the Accord that supervisory review would result in setting the baseline capital requirement at a higher level for all institutions if factors in a specific country's macroeconomic environment - for example, excessive reliance of the export of a few commodities - warranted it. In this sense, the rules-based aspect of the Accord was only to be one element in determining whether or not a bank could be regarded as well-capitalized, and the actual capital ratio set for each institution would reflect the process of supervisory judgment. As the first chairman of the Basel Committee, Sir George Blunden, once remarked, a capital ratio was valuable as "a yardstick, not a categorical imperative (Blunden, 1975).”

Thus, the banks which operated at the 8 percent minimum were to have been the best managed and well-diversified institutions operating from the G-10 industrialized countries; to the extent that most banks were less welldiversified or were comparatively lacking in risk management capacity, or 
that they operated in a more volatile macroeconomic environment, they would be expected to maintain a capital ratio in excess of the 8 percent minimum. In this respect, therefore, the process of supervisory review was intended to compensate for those elements of a bank's risk profile that were left out of the Accord's framework. Thus, the criticism, for example, that the risk measurement framework made no allowance for well-diversified portfolios was answered by the argument that only banks with welldiversified portfolios should be able to operate at the 8 percent minimum. To the extent that a bank had a more concentrated portfolio, this would be identified through the process of supervisory review, and a higher capital requirement would be set.

In practice, however, this feature of the Accord's methodology has not played the central role that was initially envisaged. Rather than employing the process of supervisory review as a supplement to the Accord's methodology, most supervisory authorities have regarded the 8 percent minimum as a "categorical imperative" rather than as a yardstick. In its application - if not the original intention - the mechanistic, rules-based features of the Accord have prevailed over its process-oriented elements. Rather than using the Accord's framework as the starting point for an assessment of capital adequacy, it has instead become a largely mechanistic process in which the only supervisory judgment has tended to be whether the Accord's rules have been complied with. This has meant that the 8 percent minimum standard has been perceived as the only standard that need apply to banks and has become synonymous with a bank being treated as "adequately-capitalized." In addition, there have been political and presentational difficulties for countries outside the G-10 to acknowledge that the 8 percent minimum may not be adequate for their banks. Although some supervisory authorities have adopted a capital requirement above the 8 percent minimum for all their institutions, ${ }^{5}$ they have been the exception rather than the rule. Instead, the 8 percent figure has been adopted as the de facto international standard.

\section{Locating the NCF on the Conceptual Map}

When contrasted with the 1988 Accord, the NCF paper involves a significant shift across both dimensions of our conceptual map. It attempts to narrow the differences that have arisen between economic and regulatory capital over the last decade, aligning the methodology for calculating regulatory capital (if not

\footnotetext{
${ }^{5}$ See footnote 4 for examples of the countries that have adopted a higher standard.
} 
the actual quantum of capital required) more closely with advances in risk management practice during the 1990s. It also involves a relative shift away from the mechanistic, formulaic approach to setting bank capital that we have characterized as "rules-driven" toward a more process-oriented form of regulation.

The methodology of the 1988 Accord may originally have been aligned with the industry standard approach to assessing capital adequacy, but the two methodologies have since drifted apart. The NCF now attempts to narrow, if not eliminate, the gap between methodologies for assessing economic and regulatory capital. The use of external ratings would align capital charges with loss risks more closely than current capital requirements. The potential use of internal rating systems and credit risk models goes even further. The endorsement of internal capital allocation mechanisms in setting regulatory capital, in effect, means the wholesale adoption, for regulatory purposes, of the methodologies for calculating economic capital currently used by the firms.

The primary difference between the NCF and the Accord is that the former's attempt to realign the methodologies of economic and regulatory capital also involves a shift in our second dimension, i.e., from rules- to process-regulation. This shift in emphasis involves foregoing the verifiability and comparability of capital ratios across banks and banking systems to the extent that it involves greater reliance on internal risk measurement and control systems. This will have important consequences. The lack of comparability of capital ratios and greater uncertainty over their derivation in the NCF will force market analysts to cease placing a burden on capital ratios that in reality they cannot bear. Instead, banks will have to be evaluated more holistically by analysts and regulators alike and capital ratios will become less comparable on their own. Capital ratios, high or low, will become more difficult to interpret and the terms "undercapitalized" and "well-capitalized" will be difficult to designate without in-depth analysis. Both analysts and regulators will need to evaluate the process of capital allocation and whether or not the level of capital adequately reflects the risks embedded in the asset portfolio.

Chart 2 traces the evolution of capital regulation since the Accord and its likely path under the NCF across the two intersecting dimensions of the conceptual map outlined above. At its inception in 1988, the Accord's methodology and its application were intended to be a mix of rulesbased minimum capital requirements and a process-oriented evaluation. The 
24 A Conceptual Map for Analyzing Capital Requirements

former would apply universally to all banks, but overlaid by a process-based evaluation of each bank that would determine whether a higher-thanminimum capital requirement would be warranted. Moreover, the minimum capital requirement was above the actual level of capital held by most banks (i.e., economic capital) in 1988 and, thus, regulatory capital exceeded economic capital.

By the early 1990s, the Accord moved across and down both dimensions of the map. First, the Accord's application was skewed heavily toward the rulebased minimum capital pillar, with few countries applying higher-thanminimum capital requirements to individual banks based on supervisory review. Second, as the actual level of capital in G-10 banking systems rose, economic capital caught up with regulatory capital. By the time the NCF was released in 1999, economic capital surpassed the minimum capital requirement, which had become largely nonbinding.

The NCF represents a movement across and up both dimensions of the chart. Regulatory capital will be realigned with, if not set higher than, economic capital, while the methodology of determining the quantum of regulatory capital will become much more process-oriented. Given the uncertainty over the extent of realignment, we have shown two possible paths for the NCF.

Chart 2. Capital Regulation Through Time

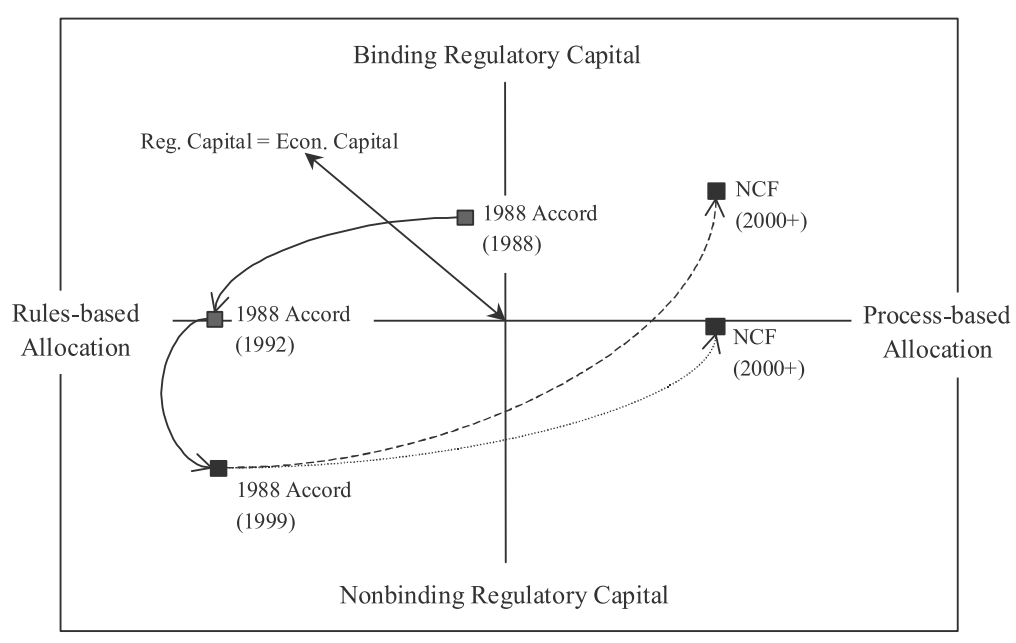

The shift of the balance from rules to processes also raises a number of fundamental issues of principle. In the first place, relying more heavily on internal capital allocation systems for setting regulatory capital will be 
problematic given that the incentive and cost functions of banks and regulators are not perfectly aligned. Whereas banks naturally focus on the private costs of failure and allocate capital accordingly, regulators must concentrate on the public costs and ensure that regulatory capital is commensurate with the latter. Economic capital determined by banks, in principle, may be too low for regulatory purposes. Admittedly, economic capital could be higher in practice where banks are more risk averse than regulators or if bank managers decide to maintain more capital to enhance their bank's reputation. Nonetheless, such cases are likely to be exceptions rather than the rule, and regulators cannot count on bank managements' conservatism to ensure that economic capital is equal to or higher than the desirable level of regulatory capital.

Thus the quantum of capital that banks are required to maintain for regulatory purposes will generally be higher than will be generated by their internal risk management systems, given the need to incorporate social costs of bank failures. In the case of the market risk amendment, regulators responded by applying a "scaling factor" of three times the internal capital requirement to the output of VaR models. An important issue in the application of the process-oriented approach for credit risk is whether a similar scaling factor will also be employed and, if so, at what level it will be set and how it will be justified.

The need for more in-depth analyses of banks under the NCF raises two additional issues, especially with respect to the third pillar. First, internal processes of capital allocation are inherently less transparent than current capital ratios. Unless essential elements of internal risk management and capital allocation mechanisms are disclosed, market participants may not have the information required to evaluate capital adequacy (though supervisors presumably would have greater access). This would undermine the market's ability to exert discipline, and along with it, the effectiveness of the third pillar. Second, even if sufficient information was available, market participants would have to devote much more resources to analyzing banks, which they may not elect to undertake given the "free-rider" problem in the market for risk analysis. The use of external credit ratings as a refinement to the current minimum standard approach may be the best compromise for regulatory capital even in advanced economies, a conclusion which follows from the discussion of external ratings and internal rating systems presented below. 


\section{The First Pillar: Minimum Capital Requirements}

The NCF's principal proposal is to replace the present system of capital charges based on four standardized risk "buckets" with one based on external credit ratings or internal risk ratings and credit risk models. The introduction of finer gradations of risk and a more analytical basis for risk buckets, in principle, represent major improvements over the existing system. However, the potential use of credit ratings raises several questions, among them the selection of rating agencies, changes in the incentives affecting the credit rating industry and borrowers, and the accuracy of ratings. Similarly, internal rating systems raise issues over their accuracy, consistency, and the incentive structures that underpin them.

\section{A. Credit Ratings}

\section{The accuracy of ratings}

The debate on rating agencies to date has been largely defined by the issue of the accuracy of ratings and whether or not they are "fit" to serve as a basis for capital charges. It is not our intention to discuss this issue in depth and it is beyond the scope of this paper to review in detail the evidence on the performance of international rating agencies. But, as detailed in the next section, analysis of internal rating systems suggests that external credit ratings may generally be more accurate and less cyclical than internal ratings. As the IMF's most recent International Capital Markets Report (1999) (the "Report") acknowledges, the agencies failed to give advance warning of the Asian crisis and steep downgrades had a procyclical effect on capital flows. It also notes, however, that the reasons were "not altogether different from why the IMF and many others were caught out."6

Importantly, the Report acknowledges the agencies' proven track record in the U.S. market - where actual default rates are strongly correlated with ratings - and that ratings may have been stabilizing rather than destabilizing during the Asian crisis. ${ }^{7}$ It cautions, however, that the agencies may not be devoting

\footnotetext{
${ }^{6}$ See IMF 1999, p. 121.

${ }^{7}$ A comparison of rating trends and spread trends (where spreads serve as a proxy for the market's view of sovereign creditworthiness) for a set of "crisis" and "noncrisis" countries revealed that rating downgrades were much less severe than the surge in loss probabilities implied by the risk premia demanded by the market. (IMF, 1999, p. 221)
} 
enough resources to conduct high quality risk analysis, and to ensure accurate and timely ratings. For example, in the area of sovereign ratings, on average one analyst is assigned by the major ratings agencies to cover seven countries. Others have also argued that country risk services underinvest in the human, information, and technological resources needed to properly analyze political, economic, and financial risks (Karacadag and Samuels, 1999). But underinvestment in analysis is not unique to rating agencies, it applies to all market participants and arguably to a greater degree.

\section{Risk analysis and ratings as public goods}

The problem of resources and underinvestment in risk analysis is deep-rooted and symptomatic of the externalities in financial markets. Providers of information and analysis have difficulty capturing the value-added created by investing in high quality analysis, which must compete with free research generated by sell-side analysts. Yet, high and low quality analyses are not always easily distinguishable. High quality analysis pays off only over the long term, but market participants, including rating agencies, are expected to deliver positive returns continuously as profit-making businesses. As a result, market participants tend to "free-ride" on readily accessible market opinion, including ratings and free research. Existing rating agencies have partially overcome this externality owing to their reputation and credibility developed over decades and the regulatory use of ratings, which enables them to charge fees from issuers. However, the free-rider problem limits the agencies' ability to maintain or augment their reputation by meeting the analytical challenges of an increasingly complex and interdependent global economy. It also underscores the challenge for new entrants, which will be even more resource-constrained.

Rating agencies provide services that, in essence, are public goods. Their increasing regulatory use both in the United States and in other developed and emerging economies reinforces the public good characteristics of the independent and objective risk analysis they provide. The agencies play a vital role in financial markets not only because ratings are used in regulation, but also because they contribute to market efficiency in two respects. First, assuming the agencies' objective and independent credit risk analysis enhance financial institutions' own risk analysis and portfolio decisions, resources are allocated more efficiently. The widespread use of rating transition matrices and default studies in credit risk models and internal rating systems, for instance, attests to the contribution of ratings to the market's risk analysis. Second, rating agencies, as market institutions, 
arguably represent financial markets' response to the public good attributes of risk analysis, whereby private resources are "pooled" in rating agencies to produce independent credit risk ratings for the benefit of all. Nevertheless, rating agencies are private companies in fierce competition with one another and accountable to shareholders with an eye to the bottom line.

The NCF's proposed use of ratings in setting capital charges subtantially increases the public good value of ratings. Yet, the additional demand for ratings induced by the NCF could cause new agencies to proliferate and competion to intensify. Pressures on the bottom line, in turn, could diminish the resources devoted to the analysis, rating, and monitoring of issuers. This underscores the importance of robust selection standards for agencies whose ratings may be used for capital charges and their consistent application. This, in turn, raises the issue of the adequacy of the criteria that the Committee proposes for the regulatory recognition of rating agencies.

\section{Criteria for the regulatory recognition of rating agencies}

The proper selection of rating agencies is a key prerequisite to the successful use of external credit ratings. The NCF proposes that national supervisory authorities approve agencies according to a predetermined set of criteria. The eligibility criteria include objectivity, track record, independence, transparency, credibility, and sufficient resources. As it stands, the proposed criteria lack the level of detail required for operational use. For example, how are objectivity and independence to be judged? What level of financial and staffing resources will be considered adequate, and on what basis?

More importantly, the application of these criteria would require discretion and subjective judgment to a degree that would make it difficult to ensure uniformity across countries. Even if the criteria included objective and wellfounded benchmarks in some areas, judgments on issues of objectivity, independence, and track record inevitably would be subjective. As a result, approval processes would be prone to inconsistencies at best and politicization at worst, especially where market discipline is weak.

The track record criterion is poorly defined in its current form. While the NCF calls for "rigorous back testing" of the ratings before approving an agency, it sets the minimum time for an agency to be in operation at only one year. The Committee appears reluctant to set a higher threshold from fear of erecting barriers to entry to the ratings industry, which is already oligopolistic. However, the attempt to strike a balance between the competing goals of 
30 The First Pillar: Minimum Capital Requirements

securing high quality ratings (based on experience and track record) and minimizing the regulatory barrier to new entrants carries risks.

First, it is unfeasible to evaluate the track record of an agency established for only one year, or even three years, because robust relationships between ratings and defaults take years, if not decades, to emerge. The fact that Moody's and Standard \& Poor's, in operation since the early 1900s, are the only two agencies that publish corporate default studies among the four NRSROs in the United States attests to the challenge of establishing and evaluating track records. ${ }^{8}$

Second, the concern over erecting regulatory barriers to entry overlooks the market-based origins of the current structure of the ratings industry. On the surface, the barriers to entry in the ratings business seem quite low, and startup costs appear minimal, comprising a few analysts, office space, computers, and data sources. With these inputs, ratings and analyses underlying them can be produced and distributed. But while ratings are opinions of creditworthiness that are nominally easy to develop, a long time is required before their value can be gauged, accuracy tested, and market participants can recognize and use them.

The present structure of the ratings industry principally stems from the importance of reputation and credibility (i.e., franchise value) as key determinants of the business success of any agency. Absent reputation and credibility, providers of risk analysis could not get paid for their work, given the vast amounts of free research generated and disseminated by market participants. As such, the time and investment required to build reputation among investors and market makers is the chief barrier to entry, and one that is considerably higher than the track record criterion contemplated by the NCF. The high fixed costs of building a reputation, coupled with the considerable economies of scale implied by those costs, underpin the concentrated structure of the ratings industry. The recent merger of FitchIBCA, the largest rating agency in Europe, and Duff \& Phelps, the third largest agency in the United States, underscores the intense competition in the sector, despite its concentrated structure, and the scale economies that need to be achieved to become competitive.

\footnotetext{
${ }^{8}$ Until recently the SEC regarded five rating agencies as NRSROs for the purposes of the net capital rule (described below), including Standard \& Poor's, Moody's, FitchIBCA, Duff \& Phelps, and Thomson BankWatch. As of June 1. 2000, FitchIBCA and Duff \& Phelps have merged to create Fitch.
} 
Setting the regulatory barrier below market-based thresholds is thus redundant where market mechanisms function, and distortionary where market discipline is inoperative. Where regulations may play a decisive role in shaping a local rating industry by spurring demand for ratings overnight, a deliberately low barrier to entry would create incentives for inexperienced and possibly incompetent agencies to operate. Thus, the thresholds used to evaluate an agency's track record should be tightened considerably, with the minimum requirement for years in operation raised to three years or more. Ultimately, the key task for supervisors is to distinguish between new rating agencies striving to build up a reputation and those intent on conquering market share and maximizing short-term profits (Benink, 1999).

The prospect of new rating agencies proliferating, particularly in less-developed emerging markets, underscores the importance of adopting strict selection criteria that are applied rigorously and consistently. Evidence suggests that new rating agencies tend to assign higher ratings (Cantor and Packer, 1994), presumably in the interest of securing the business of fee-paying issuers. This observation is consistent with the intuitive notion that reputation and the incentive to assign higher ratings are inversely related. To the extent that an agency already has amassed a reputation in the marketplace, it is unlikely to trade off its reputation for short-term gains in market share and revenue. Conversely, an agency with no reputation has less to lose by assigning higher ratings to gain market share, and therefore faces a stronger incentive to do so. This analysis is supported by evidence from the banking industry, where franchise value is shown to play a disciplining role. Studies of bank holding companies and savings and loan institutions in the United States find that institutions with high franchise value maintain more capital and assume less risk than those with low franchise value (Demetz et al, 1996; and Brewer and Saidenberg, 1996).

Even though ratings supplied by (new) third agencies are higher, evidence from the U.S. market also suggests that the prospect of receiving a higher rating does not drive requests for third ratings. Instead, U.S. firms' decision to solicit a rating from a third rating agency is a function of firm size and age (Cantor and Packer, 1995). This could suggest that in developed markets where reputation and credibility count, borrowers are unlikely to seek a third rating just because it may be higher. ${ }^{9}$ However, in markets where reputation

\footnotetext{
${ }^{9}$ However, an earlier study by the same authors found that issuers rated near the investmentgrade/speculative-grade border were more likely to request a third rating. Among those firms with split initial ratings (i.e., one investment-grade and one speculative-grade) that requested a third rating, 85 percent of them received a second investment-grade rating (Cantor and Packer, 1994).
} 
and credibility count for less, "cherry-picking" of rating agencies by issuers in search of the highest rating could shape rating demand patterns.

\section{The U.S. Securities and Exchange Commission's NRSRO designation}

In the context of the Committee's proposal, it is instructive to review the origins of NRSROs in the United States and the SEC's review process for them. The SEC's regulatory use of ratings and the term NRSRO initially was adopted in 1975 for the narrow purpose of distinguishing different grades of debt securities under the SEC's net capital rule (SEC, 1997). ${ }^{10,11}$ Since then, the SEC has employed ratings for a wide range of regulatory purposes, which include distinguishing between securities that may be issued using simplified registration procedures, and limiting the types of securities in which money market funds can invest. (SEC, 1994)

The SEC's review process in designating NRSROs heavily relies on market makers and participants. The SEC states that "the single most important criterion is that the rating organization is nationally recognized, which means that the rating organization is recognized in the United States as an issuer of credible and reliable ratings by the predominant users of securities ratings (SEC, 1997, emphasis added)." In order to determine whether an agency is nationally recognized, the SEC contacts a sample of market makers, ascertaining the degree to which an agency's ratings are known and relied upon. The SEC assesses several other factors, including the organizational structure of the agency, the agency's financial resources (to ensure its independence from the companies it rates), the size and quality of the agency's staff, and its rating procedures. However, none of the secondary criteria have specific quantitative benchmarks, because of the difficulty in "drawing the line." ${ }^{2}$ Instead, the Commission makes a qualitative judgment

\footnotetext{
${ }^{10}$ The net capital rule (Rule 15c3-1) requires a broker dealer to reduce the value of the securities positions that it owns by specified percentages when calculating its capital. Brokerdealers that own commercial paper, nonconvertible debt securities, and nonconvertible preferred stock are allowed to reduce their haircuts for these instruments when computing capital if the instruments are rated investment grade by at least two NRSROs.

${ }^{11}$ It is worth noting that the regulatory use of ratings more generally predates the SEC's use of ratings and NRSROs designation. The first usage goes back to the 1930s, when the Office of the Comptroller of the Currency and the Federal Reserve Board restricted banks to investing in investment-grade securities. For a comprehensive list of the regulatory use of ratings in the United States and selected industrial and emerging economies, see IMF (1999).

${ }^{12}$ Based on discussions with representatives of the SEC.
} 
on the combination of all factors, with market feedback serving as the decisive factor. The burden of subjective judgment ultimately rests on the shoulders of the market.

The SEC's overall experience and acceptance of the primacy of market over "administrative" criteria suggest that the NCF's rating agency selection criteria maximize the market's input into the approval process, especially in developed economies. While the regulatory use of ratings may be grounds for a more "bureaucratic" approval process, a centralized assessment of an agency's competence is unlikely to be superior to the market's collective judgment on an agency's credibility and reputation. Admittedly, reliance on a market-based approval process in most emerging markets, where market discipline is weak, is not a realistic policy option. Thus, an official review and approval process based on a set of eligibility criteria is inevitable for many countries.

Nonetheless, the NCF in its current form underestimates the range of inconsistencies that could emerge in applying subjective criteria when the responsibility for approving agencies is delegated to national authorities. A number of thorny issues arise. First, in countries where the approval process is more lenient, and quality of ratings on borrowers is lower, the ability of capital standards to achieve banking system soundness and a level playing field would be compromised. Second, policies will have to be developed on how to handle rating differences among approved agencies on the same borrower. Third, consistency among international and local rating agencies on rating definitions and scales is a key prerequisite for the successful use of ratings. In this regard, Standard \& Poor's has proposed that some kind of public concordant on domestic rating scales be reached to assure international comparability (Standard \& Poor's, 1999). Events of default and rating definitions differ even for the two largest international rating agencies, Moody's and Standard \& Poor's. Some preliminary work has already been undertaken on benchmarking individual agencies' ratings into a common measurement framework, which would achieve comparability by "denominating" ratings in their implied default rates based on historical track records (Duchataeu and Mann, 2000). ${ }^{13}$ Inconsistent approaches in any one of these areas would undermine the use of external ratings' intended contribution to increasing the precision and effectiveness of capital standards.

\footnotetext{
${ }^{13}$ Ideally, ratings would be "denominated" in implied loss rates, rather than default rates, but systematic data on recoveries is not available.
} 
The potential problems associated with a decentralized approval system can be avoided by centralizing the approval of eligible rating agencies, perhaps involving the participation of multilateral financial institutions or a representative group of local supervisory authorities meeting under the auspices of the BIS. A central authority would ensure consistent application of the selection criteria and develop a uniform approach to resolving administrative questions that would be applied universally. Undoubtedly, vesting considerable power in a central authority, whose decisions affect the business prospects of new rating agencies, could be a source of political pressure. Such pressures are more likely to be resisted, however, by a single authority managed transparently under the scrutiny of global capital markets than several authorities, some of which may be operating in environments with limited market discipline.

\section{B. Internal Rating Systems}

The NCF's proposal to use internal risk ratings in capital charges has gained momentum in recent months as the role of external ratings has become - in our view - unduly more controversial (The Economist, 1999). Critics of external ratings are most concerned about the volatility of ratings and their procyclical impact on capital flows, but the discussion continues to be overshadowed by recent events in Asia.

In principle, internal ratings have important advantages over external ratings. Internal ratings potentially incorporate proprietary information on bank clients that is unavailable to the public at large and to rating agencies, if the borrower is not rated. The informational advantage of internal systems could help generate more accurate credit risk assessments on the borrower. Accurate assessments, in turn, would minimize the difference between regulatory and economic capital. In addition, the use of internal ratings places the responsibility of risk management squarely where it belongs: within each bank, a trend the NCF intends to accelerate. However, the BIS's survey on internal rating systems (IRSs) and another conducted by the Federal Reserve reveal several aspects of IRSs that raise serious questions about their use in capital charges (BIS, 2000; Carey and Treacy, 1998). ${ }^{14}$

The specific elements of IRSs and their operation differ substantially across banks. First, the types of IRSs span a continuum ranging from statistical-

${ }^{14}$ The Committee surveyed around 30 large, diversified, international banks, while the Federal Reserve study is based on the 50 largest banks in the United States. This section is largely based on the findings of these two surveys. 
based systems to solely judgment-based systems. ${ }^{15}$ Second, banks have divergent views on what constitutes potential weaknesses with respect to their exposures. Third, banks differ on the mix of qualitative and quantitative risk factors they use and the weights they assign to each factor. Fourth, while some banks have one-dimensional rating systems, in which ratings are assigned to the borrower, others maintain two-dimensional systems, with the borrower's rating juxtaposed with a rating on the specific facility. ${ }^{16}$ Fifth, the number of grades covering nonimpaired assets ranges widely from 2 to $20 .{ }^{17}$

The differences in IRSs go beyond pure mechanics and extend to their purpose and function. For example, the main function of a system in some banks is to identify deteriorating loans, whereas in others it is used to compute internal profitability measures. These, in turn, affect the compensation of relationship managers. In about 40 percent of U.S. banks surveyed, relationship managers, as opposed to credit staff, have primary responsibility for assigning internal ratings, creating potential conflicts of interest. ${ }^{18}$ The use of IRSs for compensation purposes places a burden on bank management to ensure that adequate controls are in place to offset the incentive to assign high ratings by relationship managers.

Regardless of the statistical orientation of their system, banks rely heavily on judgment. Even banks with statistical-based systems are cognizant of the limitations of models and believe that well-managed judgment-based systems deliver more accurate risk assessments. A key reason is that statistical models analyze fixed sets of ratios and apply fixed weights to each indicator, whereas the appropriate approach to financial analysis depends on the borrower's particulars. Moreover, banks appear to have limited data and techniques available to estimate loss characteristics (i.e., the probability that a borrower in a given risk bucket will

\footnotetext{
${ }^{15}$ The specific issues raised by credit risk models are discussed in the next sub-section.

${ }^{16}$ Specific factors reviewed in rating a facility include collateral taken, seniority, and other structural features.

${ }^{17}$ Internal rating systems with a larger numbers of grades are more costly to operate, given the extra work required to distinguish finer degrees of risk. The majority of U.S. banks surveyed expressed an interest in increasing the number of grades, but among those that expressed such intentions, most of them had no active effort in progress (Carey and Treacy, 1998).

${ }^{18}$ Relationship managers' primary goal is to generate loan business at the highest possible risk-adjusted return on capital (RAROC). Therefore, they have an incentive to provide overly favorable credit assessments of their potential clients. By contrast, credit staff's main responsibilities are to undertake risk analysis in the interest of managing the bank's overall exposure and credit risk. As such, they are more independent.
} 
default, and the loss likely to be incurred in the event of a default.), given their short data histories. Available data sources that are incorporated into the models have large inconsistencies, including different definitions of loss and default. ${ }^{19}$ Even though banks have started to collect data, they remain years away from deriving meaningful default probabilities and loss estimates from their figures. Finally, only a minority of banks claim to back-test their models, and little information exists on the validation processes and results.

Thus, models are regarded as providing only indicative ratings, which are modified by loan officers and management. The importance accorded to evaluating the management of a potential borrower, in particular, necessarily requires subjective judgment by the bank. However, the principles and guidelines regarding which factors to evaluate and how to assess them are usually worded in broad terms with scarce details on weights to assign to each factor. Rating criteria are often anchored in institutional culture rather than written policy, and nurtured and developed through training, mentoring, and experience.

Another key feature of internal rating systems is that they are point-in-time assessments of borrower creditworthiness. Almost all banks surveyed indicate that they base internal ratings on a borrower's current condition, usually with a time horizon of one year. Rarely do they attempt to see through the cycle by taking a long-term view and incorporating downside scenarios into the ratings. This renders internal ratings more procyclical than the ratings of agencies, which at least attempt to see through the cycle.

A survey of 100 small, medium, and large U.S. banks indicates that the systems of small- and medium-sized banks mirror the characteristics of large banks, but are much less sophisticated (English and Nelson, 1998). First of all, not all of the smaller banks (15 percent) have rating systems for business loans. Moreover, those with rating systems have fewer risk categories. While one-half of the smaller banks assigned 75 percent or more of their new business loans to a single rating, less than one-eighth of the large lenders did the same. Not unlike their large counterparts, the internal ratings of small- and medium-sized banks are primarily based on the judgment of loan officers.

\footnotetext{
${ }^{19}$ In contrast to banks, external rating agencies have long time series on historical ratings and default rates, which banks frequently use in their models. However, the mapping of rating agency data to internal rating or credit model grades can lead to materially inaccurate estimates of default probabilities for internal grades.
} 
Perhaps most telling is English and Nelson's empirical assessment of the relationship between internal risk ratings and loan delinquency, which yields counter-intuitive results. For instance, according to their internal ratings, smaller banks appear to be making safer loans than large banks, but their delinquency and charge-off rates are higher than those of large banks. Moreover, banks' (small, medium, and large) charge-offs on business loans bear no statistical relation to the share of high-risk loans. Instead, charge-offs are positively correlated with the share of low risk loans, the exact opposite of what one would expect. Even when regressions were run separately for small, medium, and large banks, only large banks exhibited a marginally significant link between the proportion of high-risk loans and delinquency rates.

\section{Credit risk models}

Credit risk models serve somewhat different purposes than IRSs, and therefore warrant a brief discussion of their own. Unlike IRSs, which assign ratings to individual loans, credit risk models usually model the risk of a portfolio of loans with similar characteristics, such as residential mortgages and consumer loans. In terms of design, whereas IRSs vary widely ranging from statistically oriented systems to judgmental systems, credit risk models are invariably statistically oriented.

Nonetheless, credit risk models possess much of the same features and drawbacks of internal rating systems. Data limitations, stemming from the scarcity of default events and the long-time horizons used to measure credit risk, remain key impediments to the design and implementation of credit risk models (BIS, 1999b). These limitations, in turn, lead banks to invoke a number of simplifying assumptions, including the independence of credit loss events, and the treatment of the level of loss given default as nonrandom. Moreover, a consensus on the shape of the probability density function of losses has not emerged, although most are assumed to have thicker tails than the normal distribution. Most importantly, analyses of the models' sensitivity to the assumptions generally are not performed, nor are periodic back-testing and validation of their predictive powers.

In another study of credit risk modeling practices concentrating exclusively on U.S. banks, the authors concluded that,

“...rapid movement to an internal models approach for setting RBC (risk-based capital) requirements against the banking book - as a replacement of the Basle Accord - would be premature 
given the current state of the art. Especially problematic is the subjectivity inherent in current credit risk modeling practices which, in conjunction with limitations of current back-testing and other validation techniques, should raise important concerns regarding the ability of banks (or supervisors) to assess model reliability in an objective manner (Jones and Mingo, 1999)."

The current state of internal rating systems and credit risk models illustrate the challenge of using them as a basis for capital charges. First, the wide range of practices and absence of agreement on any particular system, even within the most advanced banks in the world, suggest that internal systems and models will continue to yield inconsistent, if not inaccurate, results. Second, the multitude of different practices, coupled with the high degree of judgment and cultural factors involved, makes internal systems difficult to evaluate, especially given the lack of consensus within banks and among supervisors on best practices.

\section{Preliminary Conclusions on the First Pillar}

The overall analysis of the pros and cons of external credit ratings, IRSs, and credit risk models suggests that the use of external credit ratings in capital charges may involve comparatively fewer disadvantages for the time being. Achieving accuracy and consistency in the methodologies and quality of ratings within and across countries, though challenging, is likely to prove easier than doing the same for a far greater number of banks with a wider range of practices. In addition, ratings are likely to be less procyclical than internal systems and models, whose short time horizon inherently makes them more procyclical.

Looking ahead, the reliability of external ratings and internal systems and prospects for their use in capital requirements will be shaped by the economics of the financial services industry. As the earlier discussion highlighted, country risk services tend to underinvest in the resources required to produce high quality analysis owing to profitability concerns. Banks are also resource-constrained and the increasing reliance on models for credit risk analysis may reflect competitive pressures that force banks to cut costs and seek more efficient ways of conducting business and risk analysis.

Further evolution of internal ratings and models through a process of trial and error therefore will be necessary before they can replace existing capital assessment methods. While the regulatory endorsement of internal capital 
allocation mechanisms will provide strong incentives for banks to develop and perfect these techniques, the ultimate benefits and limitations of internal mechanisms need to be better understood before using them as a substitute for regulatory capital requirements. Internal capital allocation processes may provide supervisors with valuable sources of additional information to factor into their assessment of capital adequacy, but it is far from clear that they are yet a potential replacement for a more standardized risk measurement framework. As the new capital standards are defined and finalized in the coming years, regulators will become more informed on the suitability of IRSs, and banks may be better poised to redress their drawbacks.

Even over the medium term, questions remain about the extent to which internal capital allocation processes can be adapted to serve regulatory capital purposes. While the Committee already has endorsed the use of internal models for determining capital charges for market risk, the proposed extension of their use to the banking book is more than just a mere expansion of their current application. Unlike the trading and derivatives book, which generally comprises less than a fifth of bank balance sheets, the banking book's share approaches two-thirds of banks' total assets. Evidence also suggests that, historically, losses from traditional banking businesses such as loans have been far greater than trading losses (Mellyn and Saal, 1998). A process-oriented approach to bank capital, and the review process accompanying it, requires supervisors to specify regulatory standards on those processes. Yet, neither banks nor supervisors possess sufficient knowledge of, or have agreed on, the best practices for these methods, which will have to be developed over time.

In the event that a consensus emerges over best practice, further questions arise concerning the extent to which they should be codified in regulation and risk-management methods should become "standardized." On the one hand, codifying best practices in regulation or the regulatory endorsement of specific risk management techniques runs the risk of reducing the diversity of techniques to the detriment of innovation and the discovery of superior techiniques. More importantly, the "standardization" of risk management practices would involve regulators in the business of banks to a degree that would imply some responsibility for regulators over the solvency and success of regulated banks (Koehler, 1999). As Koehler pointedly observes, "To the extent that bankers act in accordance with an increasing volume and detail of regulation, they have, in effect, succeeded in outsourcing an important part of their responsibilities." An endorsement by regulators of banks' risk management practices, thus, could create moral hazard problems of its own. 
40 The First Pillar: Minimum Capital Requirements

On the other hand, if regulations and standards are broad-brushed, the full discretion accorded to banks and supervisors may result in a wide range of risk management and supervisory review practices in terms of quality and rigor, undermining the effectiveness of capital standards. 


\section{The Second Pillar: Supervisory Review}

Under the NCF, supervisory review will become an integral part of capital standards and an essential complement to the first pillar. Supervisory review is assigned the task of ensuring banks operate above minimum regulatory capital ratios and maintain adequate internal risk control and capital allocation processes. The critical role of supervisory review in the NCF as a whole, especially if a process-oriented approach to bank capital is adopted, means that supervisory capacities will have to be upgraded in both developed and emerging economies.

As was discussed earlier, the concept of supervisory review was intended to play a central role in the 1988 Accord, but failed to become established as integral to its risk assessment methodology. The NCF framework paper attempts to reintroduce the process of supervisory review in a way that cements it as part of the process for determining the required capital ratio. According to the NCF, the review of banks' capital adequacy will be based on a variety of factors, including the experience and quality of bank management, its risk apetite and track record in managing risk, and the adequacy of risk management systems and controls (BIS, 1999c). But making supervisory review central to the assessment of capital adequacy presents several important challenges. The first problem is to ensure that the attempt to integrate the supervisory pillar into the quantitative assessment of capital requirements does not suffer the same fate as in the 1988 Accord. This requires some consideration of the factors that may have contributed to supervisory review dropping out of the way the Accord was operated in practice. On the assumption that supervisory review can be more successfully integrated as part of the NCF, the second problem is to ensure that it can be operated effectively. The solutions to these two problems are very closely linked. To understand why, it is necessary to introduce another pair of concepts - in this case, the contrast of supervision and regulation.

Regulation and supervision may be characterized as two fundamentally different approaches to the same task (Quinn, 1993). Regulation is related to our earlier concept of a rules-based approach to setting capital requirements since it is concerned with the formulation of precise rules and monitoring compliance with those rules. It employs standardized approaches to risk measurement and assessment, and demands comparatively little in terms of judgment from individual bank regulators and examiners. It may, somewhat 
crudely, be characterized as regulation by algorithm. In theory, it would be possible to reduce a large part of the regulatory task to a computer-based algorithm, for example, for calculating a few key ratios.

By contrast, supervision is concerned with formulating general guidelines rather than prescriptive rules. Within the broad framework of these guidelines, individual supervisors are encouraged to employ their own judgment, based on a detailed understanding of the institution and its business, to determine the most appropriate standards, including the capital ratio, required of individual institutions. Its leading characteristics are that it aims to be flexible, individual, and participative. It is flexible in that it does not aim to try to make individual banks conform to rigid patterns, and its aim is to examine "each bank...as an individual entity" using critiera that "must be adaptable to changing circumstances (Blunden, 1975)." It is individual in the sense that it holds that each bank must be judged according to its specific circumstances, including a judgment of the quality and capacity of its management. Finally, it is participative in that it aims to encourage a dialogue between regulators and bank management; rather than adopting an adversarial stance toward a regulated entity, regulators instead treat management as partners in determining the extent of the risks to which the institution is exposed and how these can be contained.

Process-oriented capital regulation and supervision in this specific sense are closely linked. Nonetheless, it is worth considering that - far from being an innovation - supervision is an old established practice that seems to have lost out to regulation over time. The techniques of supervision developed out of a set of very specific circumstances; they were practised, above all, by the Bank of England at a time when it was able to rely on its powers of "moral suasion" over the banking sector rather than on formal legal powers. This, in turn, was a product of a highly concentrated banking sector in which a few large banks shared a sense of belonging to a common "club." ${ }^{20}$ Indeed, supervision as practised in this form grew out of what were essentially a set of club rules with the Bank of England as the presiding judge. It relied on a series of social norms, which have been defined by Young (1993) as "a pattern of behavior that is customary, expected and self-enforcing." Where banking sectors have been larger and more diversified, as in the United States, regulation rather than supervision has been the norm. Even in Britain the framework of banking regulation has been pushed by a variety of

\footnotetext{
${ }^{20}$ The classic works on the theory of clubs are those of Buchanan (1965) and Olson (1965).
} 
pressures in a more regulatory and less supervisory direction (Schooner and Taylor, 1999).

Indeed, as other countries have striven to develop their supervisory capacity in recent decades, regulation rather than supervision has been the preferred form, since many of the self-regulating aspects of club rules have been absent from their banking systems and are difficult to create without an appropriate cultural and institutional background. These observations suggest one reason why the supervisory aspects of the Accord did not attract the importance in practice that was originally intended for them. Put simply, the institutional infrastructure necessary for the techniques of supervision to be operated effectively were absent from many of the countries that have adopted the Accord. In consequence, the emphasis came to be placed predominantly on its rules-based aspects.

The second reason why supervision may have lost out to regulation is that it is extremely intensive of human capital. A supervisory approach, with its heavy reliance on the judgment of individual supervisors, requires experienced and highly skilled personnel. By contrast, a regulatory approach can supplement the inexperience or comparatively low skills of staff with computer algorithms. Whereas the Accord's risk assessment framework represents a relatively objective measure of a bank's capital adequacy, the process of supervisory review calls on bank regulators to make judgments that are inherently subjective and may be difficult to defend, especially in the context of the dialogue between management and regulators that the supervisory approach aims to encourage. At the very least, it requires skilled and knowledgeable supervisors who will be able to explain and defend their decisions, especially as the imposition of a higher capital requirement has a direct impact on the firm's costs. In the circumstances, it may not be surprising if a combination of inexperience and risk aversion among many bank regulators has resulted in their concluding that capital requirements are best approached from a standpoint in which they can achieve a degree of quantification, albeit a crude one, since this provides an objective measure about which there can be little scope for argument.

The subjective, judgmental element of supervisory review also presents problems from the point of view of maintaining international equivalence in the application of capital standards. Evaluating the range of factors contemplated by the Committee inevitably involves discretion and subjective judgment, which would make it virtually impossible to secure consistent application of review standards worldwide. Moreover, supervisors would 
have an incentive to apply lenient standards to their domestic banks in the interest of according them with a competitive advantage. Hence, the greater the role for supervisory review, the less the Basel framework will be able to act as an internationally accepted common metric for assessing banks' capital adequacy. At a minimum, consistent application of review standards within and across countries will require some degree of coordination. While outlining a set of basic principles and guidelines would help with the process of supervisory review, they cannot substitute for the large element of judgment and differences in application that are bound to arise.

Potentially, therefore, pressure might build for the use of a peer-group review mechanism so that the processes by which bank supervisors reach their judgments are subjected to independent outside scrutiny. This may be necessary if some consistency of supervisory judgment is to be maintained and if supervisors from different jurisdictions are to have confidence in each others' supervisory judgments. However, the concept of peer review has been mooted in the past with little success. There is a widespread perception that the process may be too intrusive and may involve supervisors in secondguessing each others' judgments in a way that ultimately may undermine mutual confidence rather than build it. An important issue for the Committee as it moves in the direction of process-oriented regulation is the extent to which it is prepared to endorse some mechanism for ensuring a broad consistency of supervisory judgment.

Within the membership of the Committee itself, there will be many difficulties in making supervisory review a major pillar of the assessment of banks' capital adequacy. However, for many other countries it will be even more difficult to make use of supervisory review without significant enhancement of their existing supervisory capacity. ${ }^{21}$ Operationalizing a supervisory framework to review capital allocation processes requires highly trained and skilled supervisors. Supervisory authorities in G-10 countries, but particularly emerging markets, will be hard-pressed to mobilize the necessary resources to establish and operate effective supervisory review functions. Most supervisory agencies in emerging economies are already

\footnotetext{
${ }^{21}$ Accordingly, technical assistance programs to build supervisory capacity may have to be adopted in several countries. Key elements of a capacity building program may include (a) a diagnostic assessment of the overall approach to supervision; (b) the implementation of a risk-based approach to onsite examination; (c) the design of early warning systems for effective offsite supervision; (d) rigorous follow-up on weaknesses identified onsite or offsite; and (e) the adoption of a comprehensive training program for the supervisory function.
} 
understaffed, and supervisors underpaid. Relying on supervisory review to a greater extent than hitherto may involve these staff in making important judgments that they may be technically ill-equipped to make, or which they find hard to maintain in the face of opposition from powerful and wellconnected senior bankers. Supervisors in many of these countries already find it hard to apply rules consistently, given the constraints of the environment in which they operate. Their task will be much more difficult if the NCF gives a greater role to supervisory judgment - and, hence, discretion - which they may be unable to exercise without strong political support and the requisite degree of regulatory independence.

These considerations suggest that supervisory review will probably have a limited role under the NCF. The most likely outcome is that extensive use of supervisory review will only be found where (a) bank regulators have the capacity and the expertise to be able to exercise it, and (b) where the institutions that are subjected to supervisory review have a sense of themselves as forming a "club" with quasi-self-regulatory aspects. These conditions are most likely satisfied in the regulation of the main internationally active and diversified banking groups. Indeed, banking on a global scale has become increasingly more concentrated and therefore "club-like." Over the decade spanning 1987-1997, the total assets of the largest 20 banks in the world increased to 36 percent of total banking assets in G-10 countries from 27 percent (see Table 1), a trend that undoubtedly has continued in recent years. These are the groups referred to by the Federal Reserve as "large, complex banking organizations (LCBOs)," and their equivalents authorized by other G-7 countries. In other words, supervisory reviews will probably only play a major role in the supervision of the 30-40 largest banking groups in the world. Indeed, it is one stated purpose of the NCF to provide the regulators of these institutions with sufficient flexibility to gain proper oversight of their operations.

Table 1: Top 20 World Banks' Assets

\begin{tabular}{ccc}
\hline & Assets & Top 20/G-10 Banking \\
& (US\$, millions) & Assets $(\%)$ \\
1987 & 3793454 & 26,6 \\
1997 & 8649636 & 35,6 \\
1998 & 9708616 & $\mathrm{n} / \mathrm{a}$ \\
\hline
\end{tabular}

Sources: The Banker, various issues, and OECD, Bank Profitability: Financial Statements of Banks, various issues. 
46 The Second Pillar: Supervisory Review

One result will be a capital standard that is more obviously two-tier than at present. On the one hand, supervisory review will play a central role in the risk assessment of the LCBOs and their equivalents; on the other hand, the rest of the global banking system (both in the G-7 and beyond) will be primarily dependent on pillars one and three for the assessment of its capital adequacy. However, as we shall now argue, the role of pillar three may be limited unless the conditions for exercising market discipline are put in place. 


\section{The Third Pillar: Market Discipline}

For the first time, market discipline is assigned an explicit and essential role in capital standards and its importance as a vital complement to the first two pillars in the NCF cannot be overstated. As capital requirements shift toward a process-oriented approach, banks' capital adequacy will be less clear-cut and more difficult to evaluate. Involving market participants as "third-party" reviewers of banks' risk management and capital allocation systems thus becomes a necessary complement to the supervisory review of capital adequacy. The "third-party" review both enhances the overall evaluation of capital adequacy and provides banks added incentive to maintain capital commensurate with their risk profiles.

Market discipline could play an equally important role in capital standards by serving the purpose of reviewing the reviewers. Supervisors not only face a technically more challenging task, but in the exercise of discretion and judgment over subjective and qualititative matters, they are likely to come under political pressure from banks and other interested parties. Market discipline could act to counter such forces and provide supervisors with incentives to conduct their responsibilities rigorously and even-handedly.

Bank disclosure is the principal instrument through which market discipline is envisaged to operate in the NCF. To this end, the Committee has issued a separate paper, outlining guidelines on the disclosure of banks' capital structures, risk exposures, and the bases of their capital ratios (BIS, 2000b). Beyond disclosure, however, the NCF offers little guidance on specific instruments and ways of enhancing market discipline.

\section{A. Conditions for Market Discipline: Are They Satisfied?}

Disclosure and transparency are necessary but not sufficient conditions for market discipline. Incentives must exist for market participants to analyze available information and exercise discipline by making considered judgments on risk and return. Ultimately, even if the market sends proper signals, market discipline works only if the recipients of those signals actually respond by altering their behavior. Each one of these essential conditions disclosure, incentives to exercise discipline, and recipient response, in turn, hinge on a set of underlying preconditions all related to governance structures. 
First, adequate accounting and audit standards are essential foundations of the information required to scrutinize firms, including financial intermediaries. In the absence of standards that ensure the reliability of financial information, disclosure by banks will be of limited value. Standards alone are clearly not enough. Putting high standards into effect hinge on an adequate supply of trained accountants and reputable auditing firms. In particular, supervisors need to ensure that banks properly value loans and allocate provisions so that disclosed information reflects the true risk profile of banks and serves as a reliable basis for market price signals. While most industrialized countries meet high accounting and audit standards, many emerging economies still need to make major improvements in this sphere. This suggests the need for the Committee to outline a complementary and detailed set of guidelines on loan valuation, loan classification, and provisioning.

Second, incentives must exist for accurate and timely disclosure. For example, the intensity of supervision of individual banks could be related to the accuracy and timeliness of their financial disclosure. Similarly, bank directors and management could be held legally accountable for the accuracy of the information provided by their bank. This is a vital part of the incentive structure created in New Zealand to underpin its largely disclosure-based supervisory regime.

Third, policies - among them government bail-outs - that shape incentives to exercise discipline should be designed in a manner that maximizes market discipline. To the extent that depositors and creditors expect the government to indiscriminately bail out failed banks and to be made whole under all circumstances, they have less reason to monitor banks, especially given the costs of gathering and analyzing information. As far as banks and uninsured creditors and depositors are concerned, a "no bail-out" policy is thus necessary to minimize moral hazard problems. This condition, too, is often violated in developed and developing economies alike, even during normal times, but especially during systemic crises where the costs of a potential systemic collapse exceed the additional payout to uninsured creditors. While the ex post costs and benefits of bail-outs often justify them, the ex ante promise and expectation of a bail-out undermines incentives for prudent and vigilant behavior on the part of lenders and depositors (Lane, 1993).

Fourth, the design of financial safety nets also shapes the incentive structure facing market agents. Information asymmetries and costs, collective action problems facing depositors, and contagion - and the negetive externalities associated with them - are well-established features of financial markets that 
justify the provision of financial safety nets as a second best solution. The related moral hazard problems, however, can be minimized by "incentivecompatible" design features, including low coverage, compulsory membership, risk-adjusted premiums, and independence (Garcia, 1999). However, Garcia's extensive survey of deposit insurance schemes in 68 countries documents numerous departures from best practices worldwide. Instituting incentive-compatible deposit insurance schemes and other elements of the bank safety net are essential to underpin effective market discipline.

Empirical studies on market discipline are relatively scarce but available evidence suggests that market signals are sent to banks in developed countries, where depositors and creditors generally demand risk premia commensurate with bank creditworthiness. Numerous studies of the U.S. market find that stock prices, subordinated debt rates, and large (insured) CD rates are responsive to bank creditworthiness (Flannery and Sorescu, 1996; and Flannery, 1998).

On emerging markets, evidence is limited and somewhat mixed. One study found funding rates (inferred by interest expenses-to-debt liabilities), but not volumes, responsive to bank fundamentals in most of the sample countries (Demirguc-Kunt and Huizinga, 1998). Interestingly, the sensivitivity of funding costs to bank creditworthiness declines in systems where deposit insurance coverage is high and the scheme is publicly administered, lending support to the argument that financial safety net designs matter for market discipline. Another analysis on Argentina, Chile, and Mexico found that bank deposit volumes vary according to bank creditworthiness, and thus depositors "punish banks for risky behavior (Peria and Schmukler, 1999)." Available studies on the subject, however, are not sufficiently broad and robust enough to conclude that market discipline ultimately works, especially in emerging markets. In fact, the prevalence of banking crises and continued financial sector fragility in many countries points to the contrary.

The ultimate test of market discipline is the extent to which institutions - bank and nonbank - respond to market signals by modifying their behavior. This, in turn, requires effective governance structures and legal frameworks. For example, shareholders' ability to influence management hinges on competent board members in an executive board that plays an active role monitoring company management. The protection of shareholder and creditor rights, the rule of law, the efficiency of courts, and corruption, which are key determinants of market incentive structures, are found to be highly correlated 
with per capita incomes (La Porta et al, 1998) and, thus, are deficient in numerous developing economies.

The foregoing analysis suggests that market discipline will not be able to perform the crucial role assigned to it in the NCF unless and until the necessary conditions are in place. However, market discipline is most likely to be absent where it is most needed, i.e., in countries with weak supervisory frameworks. An important way of fostering the conditions for market discipline would be to open the domestic banking sector to foreign banks, which can bring superior risk management practices and information systems to the local market. Greater competition, in turn, would exert pressure on domestic banks to improve their banking practices and disclosure in order to maintain market share and franshise value.

The importance of instilling market discipline quickly in emerging markets has prompted some to propose the introduction of a subordinated debt requirement for banks. (Calomiris, 1998) Requiring banks to issue subordinated debt would place them under the scrutiny of a class of debt holders that have strong incentives to monitor banks. As uninsured creditors, subordinated debt holders would have much greater incentive to discipline banks compared to insured depositors. Moreover, unlike shareholders, who face both upside and downside potential, subordinated debt holders would obtain no benefit on the upside, but pay dearly on the downside. Besides serving a disciplinary role for banks, the prices at which subordinated debt is issued and traded would convey valuable information to market participants and regulators.

At face value, the subordinated debt proposal has certain theoretical advantages that merit strong consideration. Evidence from Argentina suggests that requiring banks to issue subordinated debt as part of a coherent set of measures - including a strictly limited safety net, high (12 percent) minimum risk-based capital requirements, the obligation for banks to obtain ratings, and a liquidity requirement - can inject credible market discipline over banks (Calomiris and Powell, 2000).

While it is beyond the scope of this paper to exhaustively review the pros and cons of this and other proposals, some questions can be posed. Requiring banks to issue subordinated debt assumes the existence of a class of nonbank investors - mutual funds, pension funds, and large companies - large enough to have an incentive to monitor issuing banks. In the absence of potential nonbank debt holders, other banks would be the only investors in the debt, 
The Third Pillar: Market Discipline 51

conveying little more information than already present in the interbank market.

More importantly, subordinated debt holders cannot act as a substitute for equity holders. If shareholders are not performing their essential governance functions and governance structures in the economy are not in place more generally, subordinated debt is unlikely to make more than a marginal contribution to market discipline. 



\section{Conclusion}

The NCF is an attempt to narrow the widening gap between regulatory and economic capital, driven by the increasing sophistication of risk management techniques and capital allocation systems in leading international banks. To this end, the NCF proposes to shift from a rules-driven approach capital to a process-oriented one through the adoption of internal capital allocation mechanisms for regulatory purposes. Supervisory review and market discipline are introduced as essential complements to the capital requirements, especially where banks' internal systems form the basis of capital allocation.

The foregoing analysis on internal rating systems and credit risk models has shown that there are some serious obstacles in the way of a more processoriented approach to bank capital. Internal systems differ widely across banks, involve considerable idiosyncratic judgment, and are "point-in-time" (rather than "through-the-cycle") assessments. Most importantly, their short track records preclude backtesting and validation for now; in consequence, an assessment of both their limits and benefits will not be possible for the foreseeable future. Without knowledge and consensus on best practices, proper supervisory review standards cannot be designed, nor can their consistent application be assured.

It is also vital to understand the forces behind the increasing sophistication and efficiency of risk management systems, before adopting them more widely for regulatory purposes. To the extent that they are primarily driven by cost-cutting concerns in response to growing competitive pressures, these processes may be symptomatic of the intertemporal asymmetry between the costs and benefits of analysis. While there may be short-term gains from underinvesting in risk analysis at the price of long-term profitability, high quality risk analysis involves short-term costs in the interest of securing higher long-term profits. This paper has not attempted to assess the degree to which externalities and asymmetries measurably distort bank behavior relating to risk management. Nonetheless, such questions underscore the need for more research on these issues before internal processes are used to set regulatory capital.

External credit ratings may have comparatively fewer disadvantages than internal systems. Despite their failure to predict the Asian crisis - in which 
they were not alone - the reputable rating agencies have a proven track record of credit risk analysis. Consequently, markets and regulators in several countries have already adopted ratings as essential inputs and determinants into risk and portfolio management in banks and other intermediaries. The fewer number of rating agencies (and therefore rating methodologies) compared to banks, moreover, would make a rating-based approach more transparent, administratively more manageable, and less burdensome on the process of supervisory review.

However, the successful use of external ratings in capital standards requires rigorous (and if possible, market-based) approval criteria and a robust approval process. The proposed delegation of rating agency approval to national authorities risks creating inconsistencies and weaknesses in the selection of rating agencies. One solution is to centralize the process within the BIS or another authority, with the participation of multilateral financial institutions or a representative group of local regulatory authorities.

The conditions for the use of supervisory review are arguably becoming reestablished given the consolidation in the banking sector in the G-10 countries, which is resulting in a small group of leading banks with club-like characteristics. However, this is likely to result in a bank capital adequacy standard that more obviously differentiates between a small group of leading institutions and the rest. Moreover, the high degree of discretion and subjective judgment involved in a supervisory review, especially in evaluating process-oriented capital allocation systems, creates room for wide inconsistencies in the application of capital standards. Ensuring that this pillar functions effectively will also require substantial investment in the human capital of supervisors in the developed world, and even more obviously in developing countries.

Market discipline may also perform a limited function under the new framework. Disclosure alone is not enough to secure market discipline. An array of governance structures, including proper accounting standards, incentive-compatible safety nets, "no bail-out" policies, the rule of law, and good corporate governance are also equally vital prerequisites. While there may be a case for the NCF to incorporate specific market-based instruments - among them, subordinated-debt and rating requirements - specific instruments and guidelines cannot substitute for basic elements of good governance and the political will to effect them. 


\section{References}

Bank for International Settlements, 1999a, "Capital Requirements and Bank Behavior: The Impact of the Basel Accord," Basel Committee on Banking Supervision Working Paper No. 1, April.

- 1999b, "Credit Risk Modelling: Current Practices and Applications," Basel Committee on Banking Supervision Publication No. 49, April.

- 1999c, "A New Capital Adequacy Framework," Basel Committee on Banking Supervision Consultative Paper, June.

- 2000a, "Range of Practice in Banks' International Ratings Systems," Basel Committee on Banking Supervision Discussion Paper, January.

- 2000b, "A New Capital Adequacy Framework: Pillar 3 Market Discipline," Basel Committee on Banking Supervision Discussion Paper, January.

Benink, Harald, 1999, "Promoting Market Discipline," The Financial Regulator, (December), pp. 43-47.

Berger, Allen N., Richard J. Herring, Giorgio P. Szego, 1995, "The role of capital in financial institutions," Journal of Banking \& Finance, 19, pp. 393-430.

Blunden, George, 1975, "The Supervision of UK Banking System," Bank of England Quarterly Bulletin, pp. 188-194.

Brewer III, Elijah and Marc R. Saidenberg, 1996, "Franchise Value, Ownership Structure, and Risk at Savings Institutions," FRBNY Research Paper No. 9632, September.

Buchanan, James M., 1965, “An Economic Theory of Clubs,” Economica 32, pp. 1-14.

Calomiris, Charles W., 1998, "Market-based Banking Supervision," The Financial Regulator, (March), pp. 33-36

Calomiris, Charles W. and Andrew Powell, 2000, "Can Emerging Market Regulators Establish Credible Discipline? The Case of Argentina, 19921998," unpublished draft paper, February.

Cantor, Richard and Frank Packer, 1994, "The Credit Rating Industry," FRBNY Quarterly Review, Summer/Fall.

- 1995 "Multiple Ratings and Credit Standards: Differences of Opinion in the Credit Rating Industry,” FRBNY Research Paper No. 9527, December.

Carey, Mark S. and William F Treacy, 1998, "Credit Risk Rating at Large U.S. Banks," Federal Reserve Bulletin, November.

Demetz, Rebecca S., Marc R. Saidenburg, and Philip E. Strahan, 1996, "Banks with Something to Lose: The Disciplinary Role of Franchise Value," FRBNY Economic Policy Review, (October), pp. 1-12. 
Demirguc-Kunt, Asli and Harry Huizinga, 1999, "Market Discipline and Financial Safety Net Design," World Bank Policy Research Paper No. 2183, September.

Duchateau, Alain, and Fiona Mann, 2000, "Framework for an Enhanced Standardized Approach," unpublished paper, February.

English, William B. and William R. Nelson, 1998, "Bank Risk Rating of Business Loans," Federal Reserve Board, Draft Paper, November.

Estrella, Arturo, 1995, "A Prolegomenon to Future Capital Requirements," FRBNY Economic Policy Review, (July), pp. 1-12.

- 1998, "Formulas or Supervision? Remarks on the future of regulatory capital" paper presented at conference at FRBNY, (February), pp. 26-27.

Flannery, Mark J and Sorin M Sorescu, 1996, "Evidence of Bank Market Discipline in Subordinated Debenture Yields: 1983-1991," The Journal of Finance, Vol. LI, No. 4 (September), pp. 1347-1377

Flannery, Mark J., 1998, "Using Market Information in Prudential Bank Supervision: A Review of the U.S. Empirical Evidence," Journal of Money, Credit and Banking, Vol. 30, No. 3, pp. 273-305.

Garcia, Gillian G. H., 1999, "Deposit Insurance: A Survey of Actual and Best Practices," IMF Working Paper No. 99/54.

Gardener, E. P. M., 1991, "International Regulation and Capital Adequacy: Perspectives, Developments, and Issues," in Bank Regulation and Supervision in the 1990s, J. J. Norton (ed.), pp. 97-120.

Greenspan, Alan, 1996, "Banking in the Global Marketplace," Speech delivered at the Federation of Bankers Associations, Tokyo, Japan, November 18, 1996, available at the Federal Reserve Board website.

- 1998, "The Role of Capital in Optimal Banking and Supervision," Keynote Address to the Conference on Capital Regulation in the $21^{\text {st }}$ Century, FRBNY, February 28.

Hayward, Peter, 1991, "Prospects for International Co-operation by Bank Supervisors," in Bank Regulation and Supervision in the 1990s, J. J. Norton (ed.), pp. 67-81.

International Monetary Fund, 1999, International Capital Markets: Developments, Prospects, and Key Policy Issues, September.

Jones, David and John Mingo, 1999, "Credit Risk Modeling and Internal Capital Allocation Processes: Implications for a Models-Based Regulatory Bank Capital Standard," Journal of Economics and Business, 51, pp. 79108.

Kapstein, Ethan B., Governing the Global Economy: International Finance and the State, (Harvard University Press: 1994) 
Karacadag, Cem and Barbara C Samuels II, 1999, "In Search of the Market Failure in the Asian Crisis," The Fletcher Forum of World Affairs, Vol. 23:1, Winter/Spring, pp. 131-144.

Koehler, Benedikt, 1999, “A Banker's View of Risk," The Financial Regulator, (December), pp. 46-48.

La Porta, Rafael, Forencio Lopez-de-Silanes, Andrei Shleifer, and Robert W. Vishny, 1998, "Law and Finance," Journal of Political Economy, Vol. 106 No. 6 (December) pp. 1113-1155.

Lane, Timothy, 1993, “Market Discipline," IMF Staff Papers, Vol. 40, No. 1, pp. 53-88.

Mellyn, Kevin L. and Matthew Saal, 1998, "A Perspective on the Risk and Regulatory Implications of Market-Centric Financial Systems," IIF 1998 Jacques de Larosiere Essay Competition Winning Essay (www.iif.com).

Moody's Investor Service, 2000, "Historical Default Rates of Corporate Bond Issuers, 1920-1999," Global Credit Research, January.

Nouy, Daniele, 1999, "The Basel Committee's Recent Work," Slide Presentation to the World Bank, September 29.

Olson, M., 1965, The Logic of Collective Action (Cambridge, MA: Harvard University Press).

Peria, Maria S. M. and Sergio L. Schmukler, 1999, "Do Depositors Punish Banks for "Bad" Behavior? Examining Market Discipline in Argentina, Chile, and Mexico," World Bank Policy Research Paper, No. 2058, February.

Quinn, Brian, 1993, "The Bank of England's Role in Prudential Supervision," Bank of England Quarterly Bulletin, 33, pp. 260-264.

Saunders, Anthony and Berry Wilson, 1999, "The impact of consolidation and safety net support on Canadian, US, and UK banks: 1893-1992," Journal of Banking \& Finance, 23, pp. 537-571.

Schaeffer, Stephen M., 1992, "Financial Regulation: The Contribution of the Theory of Finance," in The Internationalisation of Capital Markets and the Regulatory Response, John Fingleton (ed.).

Securities and Exchange Commission, 1994, Concept Release on Nationally Recognized Statistical Rating Organizations, Release Nos. 33-7085; 3434616; IC-20508; File No. S723-94.

- 1997, Proposed Rule on Capital Requirements for Brokers or Dealers Under the Securities Exchange Act of 1934, Release No. 34-39457; File No. S733-97.

Schooner, Heidi M. and Michael Taylor, 1999, "Convergence and Competition: The Case of Bank Regulation in Britain and the United States," Michigan International Law Review, (Summer). 
Standard \& Poor's, 1999, "Standard \& Poor's Official Response to the Basel Committee's Proposal," Bank Rating Service, December.

Standard \& Poor's, 2000, "Ratings Performance 1999: Stability \& Transition," February.

The Economist, 1999, "Bolstering Basle's Cushion," November 27December 3.

Taylor, Michael, 1998, "Now we are ten," The Financial Regulator, (September), pp. 31-34.

Young, H. Peyton, 1993, “The Evolution of Conventions," Econometrica, 61, pp. 57-84. 







\section{SUERF STUDIES}

1. George M.M. Gelauff and Corina den Broeder, Governance of Stakeholder relationships; The German and Dutch experience, Amsterdam, 1997. ISBN 90-5143-024-8.

2. Rolf Skog, Does Sweden Need a Mandatory Bid Rule? A Critical Analysis, Amsterdam, 1997. ISBN 90-5143-025-6.

3. Corporate Governance in Central and Eastern Europe; Transition Management is a Tough Job. Two papers. Amsterdam, 1998.

ISBN 90-5143-027-2.

Debora Revoltella, Financing Firms in East European Countries: An Asymmetric Information and Agency Costs Approach.

Peter H. Haiss and Gerhard Fink, Seven Years of Financial Market Reform in Central Europe.

Joseph Bisignano, Towards an Understanding of the Changing Structure of Financial Intermediation; An Evolutionary Theory of Institutional Survival, Amsterdam, 1998, ISBN 90-5143-026-4.

5. David T. Llewellyn, The New Economics of Banking, Amsterdam,1999. ISBN 90-5143-028-0.

6. John Calverley, Sarah Hewin, and Kevin Grice, Emerging Stock Markets after the Crisis, Amsterdam, 2000. ISBN 90-5143-029-9

7. Strengthening Financial Infrastructure: Deposit Insurance and Lending of Last Resort. Two papers. Amsterdam, 2000.

ISBN 90-5143-030-2.

Richard Dale, Deposit Insurance in Theory and Practice.

Christian de Boissieu and Franco Bruni, Lending of Last Resort and Systemic Stability in the Eurozone. 